\title{
Combined effects of chromium and arsenic on rice seedlings (Oryza sativa L.) growth in a solution culture supplied with or without $P$ fertilizer
}

\author{
HUANG YiZong, HU Ying ${ }^{*} \&$ LIU YunXia \\ Research Center for Eco-Environmental Sciences, Chinese Academy of Sciences, Beijing 100085, China
}

Received August 19, 2009; accepted March 9, 2010

\begin{abstract}
The growths of two rice genotypes (Jin23A and CDR22) under the coexistence of As and $\mathrm{Cr}$ in solution culture with and without $\mathrm{P}$ were investigated. The result showed that rice shoot dry weight decreased due to the complex contamination of As and $\mathrm{Cr}$, however, the influences on plant height, root length and root dry weight were insignificant.
\end{abstract}

Complex contamination of As and $\mathrm{Cr}, \mathrm{P}, \mathrm{Fe}$, rice

Citation: Huang Y Z, Hu Y, Liu Y X. Combined effects of chromium and arsenic on rice seedlings (Oryza sativa L.) growth in a solution culture supplied with or without P fertilizer. Sci China Life Sci, 2010, 53: 1459-1466, doi: 10.1007/s11427-010-4110-5

Arsenic (As) is an element which naturally occurs in the Earth's crust, and it exists in an organic or inorganic form. Its abundance in soils is $5-10 \mathrm{mg} \mathrm{kg}^{-1}$ [1,2]. Arsenic pollution occurs in areas with the release of As into soil and/or water due to arsenic-bearing mineral weathering. Arsenic pollution may also result from such human activities as mining and smelting, the use of As-containing wastewater, and the application of arsenic-bearing fertilizer and pesticides [3].

Arsenic-bearing mines are widely distributed in the provinces of middle-south and southwest China, e.g., Hunan, Yunnan, Guangdong and Guangxi Zhuang Autonomous Region. The soils and water systems near such mines may be polluted by the activities of mining and smelting. For example, according to a report by Song et al. [4], the Jindong village area of the Diaojiang basin in Guangxi is experiencing severe As pollution: the As concentrations in topsoils (0-15 $\mathrm{cm})$ and subsoils (15-30 cm) are over 200 and 500 times the As concentrations according to Level III of Chinese Soil Environmental Quality Standard. A large expanse of rice fields are polluted by As in Changning county of Hunan

*Corresponding author (email: huying@ rcees.ac.cn)
Province, and the As concentrations in soils are between 92 and $840 \mathrm{mg} \mathrm{kg}^{-1}$. The soil As concentration in more than 8000 hectares of rice fields in Hubei Province is much higher than the background value in the area [5]. Ure and Berrow found that the long term use of arsenic-bearing pesticides is associated with As accumulation in soils, and the concentration may reach $366-732 \mathrm{mg} \mathrm{kg}^{-1}$ [2].

Rice is one of the staple food crops in China and other Asian countries. About $90 \%$ of international rice production is drown in Asia. In the primary Asian rice producing nations, e.g., Bangladesh, China and Thailand, the farmland and groundwater have been polluted by different levels of As. Meharg and Rahman [6] were the first researchers who investigated the effect of As on rice growth in Bangladesh. It was found that As concentrations in rice grains increased with the use of arsenic-bearing groundwater. Similar results were obtained in Bangladesh, and west and middle India [7,8] by other researchers. Abedin found that long-term irrigation of rice plants with arsenic-bearing wastewater not only caused rice field pollution but also led to as high as $200 \mathrm{mg} \mathrm{kg}^{-1}$ of As in rice straw, which may be used as cattle food [9]. 
With the wide application of chromium $(\mathrm{Cr})$ in industries and due to the absence of proper treatment of Cr-bearing wastewater before flowing into agricultural fields, the soil $\mathrm{Cr}$ concentration in certain areas has exceeded the regulated standard. The harmfulness of chromium to the soil-plant system has been identified by scientists and aroused public attention. Zayed et al. [10] investigated the uptake and accumulation of $\mathrm{Cr}^{3+}$ and $\mathrm{CrO}_{4}{ }^{2-}$ by 11 vegetable species. They found that the above-ground parts and the under-ground parts of the plants had different $\mathrm{Cr}$ accumulation behavior, and different species behaved differently. Compared to the control treatment, the $\mathrm{Cr}$ uptake by chickpeas inoculated with nodule bacteria respectively decreased by $14 \%, 34 \%$ and $29 \%$ in the roots, shoots and grains [11]. Gardea-Torredey et al. [12] also investigated the uptake of $\mathrm{Cr}^{3+}$ and $\mathrm{Cr}^{6+}$ by tumbleweeds.

However, in practice, soil pollution often arises from multiple pollutants rather than from any one individual pollutant. It has been found that soils around mines and smelting works generally have complex contamination by several heavy metals, e.g., As, $\mathrm{Cr}, \mathrm{Cd}, \mathrm{Cu}$ and $\mathrm{Zn}$ [13]. The investigation of a single pollutant inadequately reveals the true mechanism of the transference, the accumulation and the biological toxicity of pollutants under coexistence. In this study, we focused on the combination of $\mathrm{As}^{3+}$ and $\mathrm{Cr}^{3+}$ to investigate their effect on the growth of two rice genotypes (JinA23 and CDR22) and on the plant uptake and accumulation of $\mathrm{Fe}, \mathrm{P}, \mathrm{As}$ and $\mathrm{Cr}$ in a solution culture with and without phosphorous $(\mathrm{P})$ addition.

\section{Materials and methods}

\subsection{Plant culture}

Two genotypes of rice (Oryza sativa L.), Jin23A and CDR22, were used in this study. Seeds were surface sterilized with $10 \% \mathrm{H}_{2} \mathrm{O}_{2}$ for $10 \mathrm{~min}$ and washed with deionized water three times. Germinated seeds were transferred into perlite and allowed to grow for 2-3 weeks until the 3-4 leaf stage. The seedling growth environment was controlled as follows: temperature $28^{\circ} \mathrm{C} / 20^{\circ} \mathrm{C}(\mathrm{d} / \mathrm{n})$, photoperiod $14 \mathrm{~h}$, light intensity $260-350 \mathrm{mmol} \mathrm{m}^{-2} \mathrm{~s}^{-1}$, relative humidity $60 \%-70 \%$.

The seedlings were transplanted into polyvinyl chloride (PVC) containers (7 cm high and $15 \mathrm{~cm}$ in diameter) with $500 \mathrm{~mL}$ of nutrient solution (constituents: $\mathrm{KNO}_{3}$ 2.0, $\mathrm{Ca}\left(\mathrm{NO}_{3}\right)_{2} \cdot 4 \mathrm{H}_{2} \mathrm{O} 2.0, \mathrm{Mg}\left(\mathrm{NO}_{3}\right)_{2} \cdot 6 \mathrm{H}_{2} \mathrm{O} 0.8, \mathrm{KH}_{2} \mathrm{PO}_{4}$ 0.7, $\mathrm{NaCl} 0.05$ (in mmol L ${ }^{-1}$ ), and Fe-EDTA 50.0, $\mathrm{H}_{3} \mathrm{BO}_{3}$ 10.0, $\mathrm{MnCl}_{2} \cdot 4 \mathrm{H}_{2} \mathrm{O} 5.0, \mathrm{ZnCl}_{2} 1.0, \mathrm{CuCl}_{2} \cdot 2 \mathrm{H}_{2} \mathrm{O} 1.0, \mathrm{Na}_{2} \mathrm{MoO}_{4} \cdot$ $2 \mathrm{H}_{2} \mathrm{O} 0.5$ and $\mathrm{CoSO}_{4} \cdot 7 \mathrm{H}_{2} \mathrm{O} 0.2$ (in $\mu \mathrm{mol} \mathrm{L} \mathrm{L}^{-1}$ ) for $15 \mathrm{~d}$ (one seedling per PVC container), and were divided into two groups: one group continued to grow in the cultural solution with phosphorous $(+\mathrm{P})\left(0.7 \mathrm{mmol} \mathrm{L}{ }^{-1} \mathrm{KH}_{2} \mathrm{PO} 4\right)$ and the other group was grown in solution without phosphorous
(-P). Two weeks later, $\mathrm{Cr}^{3+}\left(\mathrm{CrCl}_{3} \cdot 6 \mathrm{H}_{2} \mathrm{O}\right)$ and $\mathrm{As}^{3+}$ $\left(\mathrm{NaAsO}_{2}\right)$ were added. Three combinations of $\mathrm{Cr}^{3+}$ and $\mathrm{As}^{3+}$ were used: $0 \mathrm{mg} \mathrm{L}^{-1} \mathrm{As}^{3+}+1.0 \mathrm{mg} \mathrm{L}^{-1} \mathrm{Cr}^{3+} ; 0.5 \mathrm{mg} \mathrm{L}^{-1}$ $\mathrm{As}^{3+}+1.0 \mathrm{mg} \mathrm{L}^{-1} \mathrm{Cr}^{3+} ; 1.0 \mathrm{mg} \mathrm{L}^{-1} \mathrm{As}^{3+}+1.0 \mathrm{mg} \mathrm{L}^{-1} \mathrm{Cr}^{3+}$. Each treatment was conducted in quadruplicate. All cultures were carried out in a greenhouse and the condition was the same as in the seedling culture. 10 days after the addition of As and/or $\mathrm{Cr}$, the plants were harvested.

\subsection{Plant analysis}

When the plants were harvested, the plant height and the root length were measured. The iron plaque on the root was extracted by dithionite-citrate-bicarbonate (DCB) [15]. Before extraction, the roots were washed with deionized water, and the roots were immediately put into containers with 40 $\mathrm{mL}$ solution of $0.03 \mathrm{~mol} \mathrm{~L}^{-1}$ sodium citrate $\left(\mathrm{Na}_{2} \mathrm{C}_{6} \mathrm{H}_{5} \mathrm{O}_{7}\right.$. $2 \mathrm{H}_{2} \mathrm{O}$ ) and $0.125 \mathrm{~mol} \mathrm{~L}-1$ sodium bicarbonate $\left(\mathrm{NaHCO}_{3}\right)$ and kept for $10 \mathrm{~min} .1 \mathrm{~g}$ of $\mathrm{Na}_{2} \mathrm{~S}_{2} \mathrm{O}_{4}$ was added and the extraction continued for one hour. After that, the roots were removed, washed with deionized water, made up to $100 \mathrm{~mL}$ and filtered for analysis. The roots and shoots were dried in an oven at $70^{\circ} \mathrm{C}$ for $72 \mathrm{~h}$, after which their weights were measured. The amount of iron plaque was expressed as the iron content extracted per unit root dry weight.

The shoots and roots were separately ground, before 0.25 $\mathrm{g}$ of each ground sample was placed into a digestion can and $5 \mathrm{~mL}$ of nitrate was added. Digestion was allowed in a microwave digestion oven (Mars 5, CEM Corporation, USA) at $180^{\circ} \mathrm{C}$ for $10 \mathrm{~min}$. During the course, standard reference material GBW07605 was applied for the quality control of the entire digestion and analysis process. After that, the digested sample was made up to $50 \mathrm{~mL}$ with deionized water and filtered. The concentrations of $\mathrm{Fe}, \mathrm{P}$ and $\mathrm{Cr}$ in $\mathrm{DCB}$ extraction solution and in the digestion solution were analyzed by ICP-MS, and the arsenic was analyzed by AFS-2202E atomic fluorescence. The recovery rate was about $95 \%$.

\subsection{Data analysis}

Iron plaque-to-shoot transference factors $\left(\mathrm{TF}_{\text {shoot }}\right)$ and iron plaque-to-root transference factors $\left(\mathrm{TF}_{\text {root }}\right)$ were calculated based on the following equations:

$$
\begin{aligned}
\mathrm{TF}_{\text {shoot }} & =\left[\mathrm{C}_{\mathrm{x} \text {-shoot }}\right]_{\text {dry }} /\left[\mathrm{C}_{\mathrm{x} \text {-rron-plaque }}\right], \\
\mathrm{TF}_{\text {root }} & =\left[\mathrm{C}_{\mathrm{x} \text { _root }}\right]_{\text {dry }} /\left[\mathrm{C}_{\mathrm{x} \text {-iron-plaque }}\right],
\end{aligned}
$$

where $\left[\mathrm{C}_{\mathrm{x} \text {-shoot }}\right]_{\text {dry }}$ and $\left[\mathrm{C}_{\mathrm{x} \text {-root }}\right]_{\text {dry }}$ respectively represent the concentration of element $\mathrm{X}(\mathrm{Fe}, \mathrm{P}, \mathrm{As}$ and $\mathrm{Cr})$ in shoots and roots, and $\mathrm{C}_{\mathrm{x} \text {-iron-plaque }}$ represents the concentration of element $\mathrm{X}$ in the iron plaque.

Distribution coefficients (DC) of Fe, $\mathrm{P}, \mathrm{As}$ and $\mathrm{Cr}$ are defined as the ratio of the total content of the corresponding element in shoots to that in roots. 
Two-way analysis of variance (ANOVA) was conducted using microsoft windows-based genstat package (6th edition, NAG Ltd., England).

\section{Results}

\subsection{Shoot height, root length and biomass}

Table 1 shows the height, root length and dry weight of the shoots and roots of the two rice genotypes grown in solutions with $1.0 \mathrm{mg} \mathrm{L}^{-1} \mathrm{Cr}$ and different concentrations of As. The table shows that the plant height, root length and the weight of the shoots and roots largely differed between genotypes $(P<0.001)$ and Jin23A grew better than CDR22. The addition of As to the cultural solution had considerable influence on the rice shoot biomass, while the impacts on the rice root biomass, plant height and root length were insignificant. In the absence of $\mathrm{P}$, the shoot weights of both rice genotypes (Jin23A and CDR22) under treatment of $1.0 \mathrm{mg}$ $\mathrm{L}^{-1} \mathrm{As}^{3+}+1.0 \mathrm{mg} \mathrm{L}^{-1} \mathrm{Cr}^{3+}$ were respectively $11.2 \%$ and $13.1 \%$ lower than that under $0.5 \mathrm{mg} \mathrm{L}^{-1} \mathrm{As}^{3+}+1.0 \mathrm{mg} \mathrm{L}^{-1} \mathrm{Cr}^{3+}$, and with $\mathrm{P}$ addition, the weights were respectively $13.8 \%$ and $6.0 \%$ lower. The addition of $\mathrm{P}$ significantly stimulated rice growth so that the weight of shoots and roots increased $(P<0.001)$, but root length exhibited no significant change.

\subsection{Fe, $\mathrm{P}, \mathrm{As}$ and $\mathrm{Cr}$ accumulation in plant tissues}

The concentrations of $\mathrm{Fe}$ in the shoots and roots of both rice genotypes significantly decreased with the increase of As concentration in the nutrient solution $(P<0.001)$. Adding $\mathrm{P}$ or not brought about a significantly different Fe concentration in plant tissues (Tables 2 and 3). Compared to the control treatment, the treatment of $1.0 \mathrm{mg} \mathrm{L}^{-1} \mathrm{As}^{3+}+1.0 \mathrm{mg} \mathrm{L}^{-1}$ $\mathrm{Cr}^{3+}$ resulted in a respective decrease of the Fe concentration in Jin23A shoots and roots of $9.4 \%$ and $27.1 \%$ in the absence of $\mathrm{P}$, and in the presence of $\mathrm{P}$, the respective decrease was $25.7 \%$ and $32.1 \%$. The Fe concentration decreases in CDR22 shoots and roots were respectively $29.8 \%$ and $35.0 \%$ in the absence of $\mathrm{P}$, and respectively $28.5 \%$ and $27.5 \%$ in the presence of $\mathrm{P}$. The concentration of $\mathrm{P}$ in plant tissues was significantly correlated with $\mathrm{P}$ addition $(P<$ 0.001). Compared to the treatment without $\mathrm{P}, 0.7 \mathrm{mmol} \mathrm{L}^{-1}$ $\mathrm{P}$ in solution led to an increase of $\mathrm{P}$ concentration in Jin23A shoots and roots by 6.1-7.4 and 3.7-5.1 times, and the increases in CDR22 shoots and roots were 6.4-8.8 and 3.6-7.7 times. The addition of As and $\mathrm{Cr}$ to the solution did not significantly influence the concentration of $\mathrm{P}$ in rice shoots and roots.

With the increase of As in the cultural solution, the root As concentration in both rice genotypes Jin23A and CDR22 increased, while the shoot As concentration did not increase, or slightly decreased. When $\mathrm{P}$ was applied, the root As concentration was significantly affected $(P<0.001)$, but the shoot As concentration showed no significant difference. Under the treatment of $0.5 \mathrm{mg} \mathrm{L}^{-1} \mathrm{As}^{3+}+1.0 \mathrm{mg} \mathrm{L}^{-1} \mathrm{Cr}^{3+}$ and $1.0 \mathrm{mg} \mathrm{L}^{-1} \mathrm{As}^{3+}+1.0 \mathrm{mg} \mathrm{L}^{-1} \mathrm{Cr}^{3+}$, the As accumulation in roots of Jin23A was respectively $7.7 \%$ and $11.2 \%$ higher in the presence of $\mathrm{P}$ than in the absence of $\mathrm{P}$, and for roots of CDR22, the accumulation was respectively $35.5 \%$ and $31.1 \%$ higher.

Table 1 Height, root length, and dry weight (DW) of shoots and roots of two rice genotypes grown in solutions with Cr (1.0 mg/L) and different concentrations of $\mathrm{As}^{\mathrm{a}}$

\begin{tabular}{|c|c|c|c|c|c|c|c|c|c|}
\hline \multirow{2}{*}{ As (mg/L) } & \multirow{2}{*}{ Genotypes } & \multicolumn{2}{|c|}{ Height $(\mathrm{cm})$} & \multicolumn{2}{|c|}{ Root length $(\mathrm{cm})$} & \multicolumn{2}{|c|}{ DW of shoot $(\mathrm{g})$} & \multicolumn{2}{|c|}{ DW of root $(\mathrm{g})$} \\
\hline & & $-\mathrm{P}$ & $+\mathrm{P}$ & $-\mathrm{P}$ & $+\mathrm{P}$ & $-\mathrm{P}$ & $+\mathrm{P}$ & $-\mathrm{P}$ & $+\mathrm{P}$ \\
\hline \multirow[t]{2}{*}{0} & $\operatorname{Jin} 23 \mathrm{~A}$ & $\begin{array}{l}52.38 \\
(0.55)\end{array}$ & $\begin{array}{l}62.53 \\
(1.81)\end{array}$ & $\begin{array}{l}23.38 \\
(1.39)\end{array}$ & $\begin{array}{l}23.13 \\
(1.03)\end{array}$ & $\begin{array}{c}2.13 \\
(0.13)\end{array}$ & $\begin{array}{c}4.06 \\
(0.17)\end{array}$ & $\begin{array}{c}0.69 \\
(0.05)\end{array}$ & $\begin{array}{c}1.13 \\
(0.14)\end{array}$ \\
\hline & CDR22 & $\begin{array}{l}38.38 \\
(0.95)\end{array}$ & $\begin{array}{l}41.38 \\
(1.89)\end{array}$ & $\begin{array}{l}21.10 \\
(0.86)\end{array}$ & $\begin{array}{l}20.88 \\
(0.63)\end{array}$ & $\begin{array}{c}1.09 \\
(0.02)\end{array}$ & $\begin{array}{c}1.50 \\
(0.21)\end{array}$ & $\begin{array}{c}0.46 \\
(0.01)\end{array}$ & $\begin{array}{c}0.46 \\
(0.04)\end{array}$ \\
\hline \multirow[t]{2}{*}{0.5} & Jin23A & $\begin{array}{l}52.90 \\
(0.67)\end{array}$ & $\begin{array}{l}62.00 \\
(0.98)\end{array}$ & $\begin{array}{l}23.38 \\
(0.38)\end{array}$ & $\begin{array}{l}23.13 \\
(0.97)\end{array}$ & $\begin{array}{c}2.41 \\
(0.08)\end{array}$ & $\begin{array}{c}3.76 \\
(0.10)\end{array}$ & $\begin{array}{c}0.84 \\
(0.05)\end{array}$ & $\begin{array}{c}1.04 \\
(0.07)\end{array}$ \\
\hline & CDR22 & $\begin{array}{l}37.50 \\
(0.61)\end{array}$ & $\begin{array}{l}43.50 \\
(0.54)\end{array}$ & $\begin{array}{l}20.75 \\
(0.32)\end{array}$ & $\begin{array}{l}20.38 \\
(0.43)\end{array}$ & $\begin{array}{c}0.99 \\
(0.10)\end{array}$ & $\begin{array}{c}1.67 \\
(0.16)\end{array}$ & $\begin{array}{c}0.47 \\
(0.04)\end{array}$ & $\begin{array}{c}0.51 \\
(0.05)\end{array}$ \\
\hline \multirow[t]{2}{*}{1.0} & $\operatorname{Jin} 23 \mathrm{~A}$ & $\begin{array}{l}52.68 \\
(0.32)\end{array}$ & $\begin{array}{l}58.80 \\
(0.39)\end{array}$ & $\begin{array}{l}20.20 \\
(0.81)\end{array}$ & $\begin{array}{l}23.20 \\
(0.56)\end{array}$ & $\begin{array}{c}2.14 \\
(0.06)\end{array}$ & $\begin{array}{c}3.24 \\
(0.20)\end{array}$ & $\begin{array}{c}0.81 \\
(0.08)\end{array}$ & $\begin{array}{c}0.92 \\
(0.06)\end{array}$ \\
\hline & CDR22 & $\begin{array}{l}35.45 \\
(1.05) \\
\end{array}$ & $\begin{array}{r}42.93 \\
(0.87) \\
\end{array}$ & $\begin{array}{l}20.38 \\
(0.94) \\
\end{array}$ & $\begin{array}{r}19.88 \\
(0.69) \\
\end{array}$ & $\begin{array}{c}0.86 \\
(0.07) \\
\end{array}$ & $\begin{array}{c}1.57 \\
(0.15) \\
\end{array}$ & $\begin{array}{c}0.48 \\
(0.03) \\
\end{array}$ & $\begin{array}{c}0.72 \\
(0.09) \\
\end{array}$ \\
\hline \multicolumn{10}{|c|}{ Analysis of variance } \\
\hline \multicolumn{2}{|c|}{ As } & \multicolumn{2}{|c|}{ NS } & \multicolumn{2}{|c|}{ NS } & \multicolumn{2}{|c|}{$P<0.05$} & \multicolumn{2}{|c|}{ NS } \\
\hline \multicolumn{2}{|c|}{ Genotypes (G) } & \multicolumn{2}{|c|}{$P<0.001$} & \multicolumn{2}{|c|}{$P<0.001$} & \multicolumn{2}{|c|}{$P<0.001$} & \multicolumn{2}{|c|}{$P<0.001$} \\
\hline \multicolumn{2}{|c|}{$\mathrm{P}$} & \multicolumn{2}{|c|}{$P<0.001$} & \multicolumn{2}{|c|}{ NS } & \multicolumn{2}{|c|}{$P<0.001$} & \multicolumn{2}{|c|}{$P<0.001$} \\
\hline \multicolumn{2}{|c|}{$A s \times G$} & \multicolumn{2}{|c|}{ NS } & \multicolumn{2}{|c|}{ NS } & \multicolumn{2}{|c|}{ NS } & \multicolumn{2}{|c|}{ NS } \\
\hline & & & & & & & & & \\
\hline & & & & & & & 001 & & \\
\hline & & & & & & & & & \\
\hline
\end{tabular}

a) Data in brackets represent the standard error. 
Table 2 Concentrations of $\mathrm{Fe}, \mathrm{P}, \mathrm{As}$ and $\mathrm{Cr}$ in shoots of two rice genotypes grown in solutions with $\mathrm{Cr}\left(1.0 \mathrm{mg} \mathrm{\textrm {L } ^ { - 1 } )}\right.$ and different concentrations of As ${ }^{\mathrm{a})}$

\begin{tabular}{|c|c|c|c|c|c|c|c|c|c|}
\hline \multirow{2}{*}{ As $\left(\mathrm{mg} \mathrm{L}^{-1}\right)$} & \multirow{2}{*}{ Genotypes } & \multicolumn{2}{|c|}{$\mathrm{Fe}\left(\mathrm{mg} \mathrm{kg}^{-1}\right)$} & \multicolumn{2}{|c|}{$\mathrm{P}\left(\mathrm{g} \mathrm{kg}^{-1}\right)$} & \multicolumn{2}{|c|}{ As $\left(\mathrm{mg} \mathrm{kg}^{-1}\right)$} & \multicolumn{2}{|c|}{$\mathrm{Cr}\left(\mathrm{mg} \mathrm{kg}^{-1}\right)$} \\
\hline & & $-\mathrm{P}$ & $+\mathrm{P}$ & $-\mathrm{P}$ & $+\mathrm{P}$ & $-\mathrm{P}$ & $+\mathrm{P}$ & $-\mathrm{P}$ & $+\mathrm{P}$ \\
\hline \multirow{4}{*}{0} & \multirow{2}{*}{$\operatorname{Jin} 23 \mathrm{~A}$} & 290.10 & 209.27 & 1.05 & 7.44 & 0.00 & 0.00 & 4.34 & 5.71 \\
\hline & & $(19.45)$ & $(16.50)$ & $(0.02)$ & $(0.28)$ & $(0.00)$ & $(0.00)$ & $(0.31)$ & $(0.25)$ \\
\hline & \multirow{2}{*}{ CDR22 } & 365.94 & 326.46 & 1.10 & 10.70 & 0.00 & 0.00 & 7.03 & 5.77 \\
\hline & & (10.69) & $(10.41)$ & $(0.03)$ & $(0.32)$ & $(0.00)$ & $(0.00)$ & $(0.43)$ & $(0.63)$ \\
\hline \multirow{3}{*}{0.5} & \multirow{2}{*}{$\operatorname{Jin} 23 \mathrm{~A}$} & 257.13 & 181.68 & 0.97 & 8.15 & 8.82 & 12.00 & 3.96 & 3.96 \\
\hline & & (17.02) & (7.19) & $(0.02)$ & $(0.11)$ & (1.37) & (1.96) & $(0.11)$ & $(0.32)$ \\
\hline & CDR22 & $(2.53)$ & (13.78) & $(0.03)$ & $(0.37)$ & $(0.64)$ & $(2.54)$ & $(0.70)$ & $(0.59)$ \\
\hline \multirow{4}{*}{1.0} & \multirow{2}{*}{ Jin23A } & 262.74 & 155.41 & 1.01 & 8.16 & 9.90 & 12.35 & 5.09 & 4.49 \\
\hline & & (20.33) & $(4.37)$ & $(0.01)$ & $(0.33)$ & $(0.91)$ & $(2.50)$ & $(0.28)$ & $(0.10)$ \\
\hline & \multirow{2}{*}{ CDR22 } & 336.97 & 233.51 & 1.19 & 8.73 & 18.75 & 15.63 & 8.09 & 6.20 \\
\hline & & $(9.80)$ & $(3.20)$ & $(0.02)$ & $(0.55)$ & (1.17) & (2.09) & $(0.79)$ & $(0.25)$ \\
\hline \multicolumn{10}{|c|}{ Analysis of variance } \\
\hline \multicolumn{2}{|c|}{ As } & \multicolumn{2}{|c|}{$P<0.001$} & \multicolumn{2}{|c|}{$\mathrm{NS}$} & \multicolumn{2}{|c|}{$P<0.001$} & \multicolumn{2}{|c|}{$P<0.01$} \\
\hline \multicolumn{2}{|c|}{ Genotypes (G) } & \multicolumn{2}{|c|}{$P<0.001$} & \multicolumn{2}{|c|}{$P<0.001$} & \multicolumn{2}{|c|}{$P<0.001$} & \multicolumn{2}{|c|}{$P<0.001$} \\
\hline \multicolumn{2}{|c|}{ As $\times \mathrm{G}$} & \multicolumn{2}{|c|}{ NS } & & & & & & \\
\hline & & & & & & & & & \\
\hline & & & & & & & & & \\
\hline As & & & & & & & & & \\
\hline
\end{tabular}

a) Data in brackets represent the standard error.

Table 3 Concentrations of $\mathrm{Fe}, \mathrm{P}, \mathrm{As}$ and $\mathrm{Cr}$ in roots of two rice genotypes grown in solutions with $\mathrm{Cr}(1.0 \mathrm{mg} / \mathrm{L})$ and different concentrations of As ${ }^{\text {a) }}$

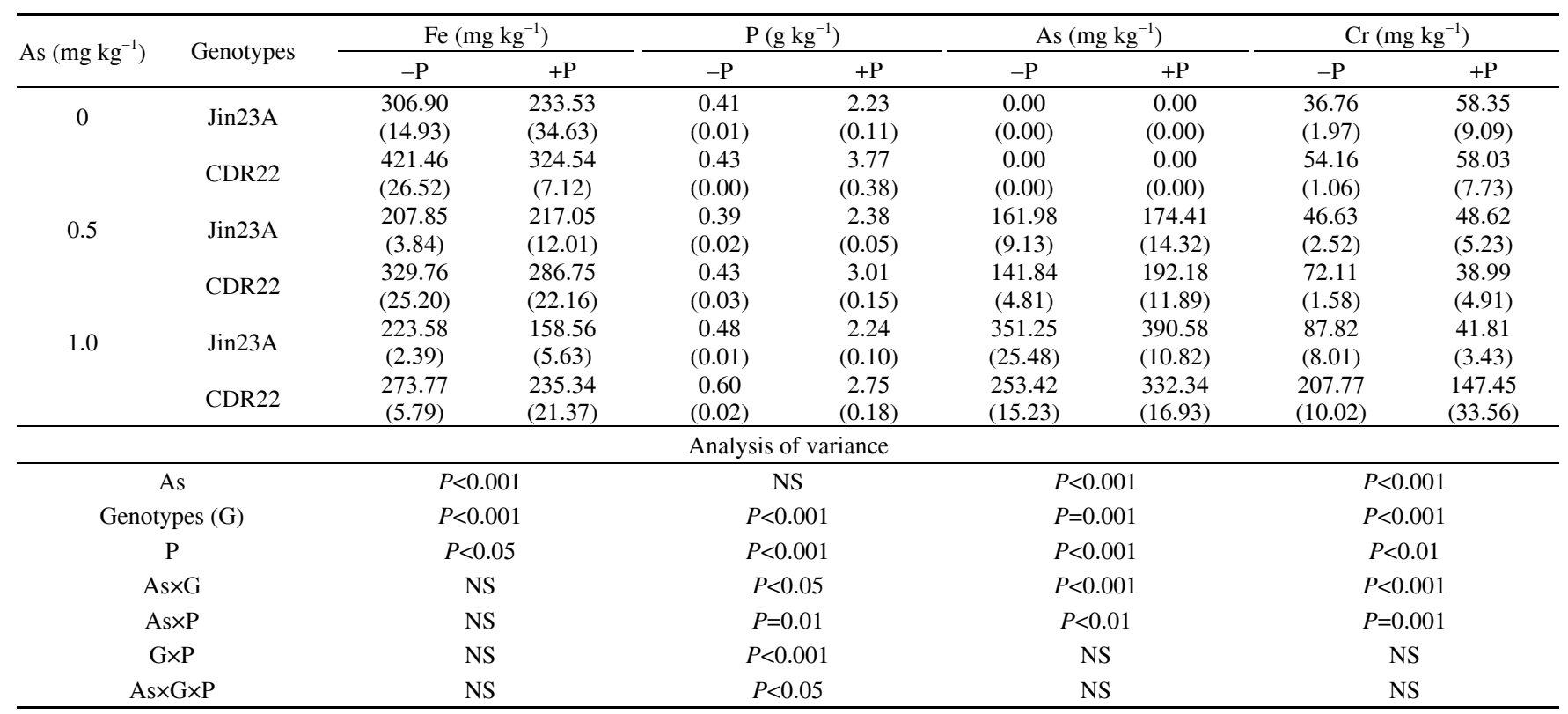

a) Data in brackets represent the standard error.

The concentrations of $\mathrm{Cr}$ in rice shoots and roots were significantly influenced by $\mathrm{P}$ and As addition $(P<0.01$, Tables 2 and 3). Generally, rice $\mathrm{Cr}$ concentration decreased with $\mathrm{P}$ addition while it increased with the increase of As in a cultural solution, especially in roots. Compared to the control treatment, $1.0 \mathrm{mg} \mathrm{L}^{-1} \mathrm{As}^{3+}+1.0 \mathrm{mg} \mathrm{L}^{-1} \mathrm{Cr}^{3+}$ in the solution respectively resulted in an increase of $\mathrm{Cr}$ concentration in Jin23A roots by $40.2 \%$ (with P) and $138.9 \%$ (without $\mathrm{P}$ ), and an increase of $\mathrm{Cr}$ in CDR22 roots by $154.1 \%$ (with $\mathrm{P}$ ) and $283.6 \%$ (without $\mathrm{P}$ ).

\subsection{Distribution and transference of $\mathrm{Fe}, \mathrm{P}$, As and $\mathrm{Cr}$ in rice plants}

The transference coefficients of Fe from the iron plaque to shoots $\left(\mathrm{TF}_{\text {shoot }}\right)$ and roots $\left(\mathrm{TF}_{\text {root }}\right)$ were respectively $0.09-$ 0.42 and $0.08-0.46$ for Jin23A, and 0.08-0.19 and 0.080.23 for CDR22 in different treatments. As and $\mathrm{P}$ addition to nutrient solution reduced $\mathrm{TF}_{\text {shoot }}$ and $\mathrm{TF}_{\text {root }}$ of $\mathrm{Fe}$, and the impact was significant for both genotypes of rice $(P<0.001$, 
Tables 4 and 5). The $\mathrm{TF}_{\text {shoot }}$ and $\mathrm{TF}_{\text {root }}$ of $\mathrm{P}$ were respectively $4.96-7.01$ and $1.36-3.17$ for Jin23A, and 2.71-4.31 and 1.29-1.55 for CDR22 in different treatments. The effect of $\mathrm{As}$ and $\mathrm{Cr}$ on $\mathrm{TF}_{\text {shoot }}$ of $\mathrm{P}$ was significant but not on $\mathrm{TF}_{\text {root }}$ of P.

There was a large difference between the transference of As from the iron plaque to the roots and shoots: the trans- ference coefficients were respectively $6.10-10.80$ and 1.73-12.38 in roots of Jin23A and CDR22, and respectively $0.17-0.76$ and $0.13-1.47$ in shoots. Compared to the transference coefficients of $\mathrm{Fe}, \mathrm{P}$ and $\mathrm{As}$, the $\mathrm{TF}_{\text {shoot }}$ of $\mathrm{Cr}$ was the smallest, less than 0.07 in all treatments, and $\mathrm{TF}_{\text {root }}$ of $\mathrm{Cr}$ was in the range of 0.22-0.78. Additionally, the addition of As and $\mathrm{P}$ significantly influenced the $\mathrm{TF}_{\text {shoot }}$ of $\mathrm{Cr}$.

Table 4 Iron plaques-to-shoot transference factors $\left(\mathrm{TF}_{\text {shoot }}\right)$ for $\mathrm{Fe}, \mathrm{P}, \mathrm{As}$ and $\mathrm{Cr}$ in two rice genotypes grown in solutions with $\mathrm{Cr}(1.0 \mathrm{mg} / \mathrm{L})$ and different concentrations of $\mathrm{As}{ }^{\text {a) }}$

\begin{tabular}{|c|c|c|c|c|c|c|c|c|c|}
\hline \multirow{2}{*}{ As $\left(\mathrm{mg} \mathrm{L}^{-1}\right)$} & \multirow{2}{*}{ Genotypes } & \multicolumn{2}{|c|}{$\mathrm{Fe}$} & \multicolumn{2}{|c|}{$\mathrm{P}$} & \multicolumn{2}{|c|}{ As } & \multicolumn{2}{|c|}{$\mathrm{Cr}$} \\
\hline & & $-\mathrm{P}$ & $+\mathrm{P}$ & $-\mathrm{P}$ & $+\mathrm{P}$ & $-\mathrm{P}$ & $+\mathrm{P}$ & $-\mathrm{P}$ & $+\mathrm{P}$ \\
\hline \multirow[t]{2}{*}{0} & $\operatorname{Jin} 23 \mathrm{~A}$ & $\begin{array}{c}0.43 \\
(0.06)\end{array}$ & $\begin{array}{c}0.13 \\
(0.00)\end{array}$ & $\begin{array}{c}5.34 \\
(0.22)\end{array}$ & $\begin{array}{c}6.03 \\
(0.38)\end{array}$ & - & - & $\begin{array}{c}0.05 \\
(0.01)\end{array}$ & $\begin{array}{c}0.07 \\
(0.01)\end{array}$ \\
\hline & CDR22 & $\begin{array}{c}0.19 \\
(0.02)\end{array}$ & $\begin{array}{c}0.09 \\
(0.01)\end{array}$ & $\begin{array}{c}3.87 \\
(0.37)\end{array}$ & $\begin{array}{c}4.28 \\
(0.25)\end{array}$ & - & - & $\begin{array}{c}0.03 \\
(0.00)\end{array}$ & $\begin{array}{c}0.03 \\
(0.01)\end{array}$ \\
\hline \multirow[t]{2}{*}{0.5} & Jin23A & $\begin{array}{c}0.35 \\
(0.01)\end{array}$ & $\begin{array}{c}0.11 \\
(0.01)\end{array}$ & $\begin{array}{c}7.01 \\
(0.13)\end{array}$ & $\begin{array}{c}6.48 \\
(0.29)\end{array}$ & $\begin{array}{c}0.35 \\
(0.05)\end{array}$ & $\begin{array}{c}0.76 \\
(0.17)\end{array}$ & $\begin{array}{c}0.04 \\
(0.00)\end{array}$ & $\begin{array}{c}0.04 \\
(0.00)\end{array}$ \\
\hline & CDR22 & $\begin{array}{c}0.12 \\
(0.03)\end{array}$ & $\begin{array}{c}0.08 \\
(0.01)\end{array}$ & $\begin{array}{c}3.11 \\
(0.48)\end{array}$ & $\begin{array}{c}4.21 \\
(0.29)\end{array}$ & $\begin{array}{c}0.36 \\
(0.09)\end{array}$ & $\begin{array}{c}1.47 \\
(0.48)\end{array}$ & $\begin{array}{c}0.02 \\
(0.01)\end{array}$ & $\begin{array}{c}0.04 \\
(0.00)\end{array}$ \\
\hline \multirow[t]{2}{*}{1.0} & $\operatorname{Jin} 23 \mathrm{~A}$ & $\begin{array}{c}0.24 \\
(0.06)\end{array}$ & $\begin{array}{c}0.07 \\
(0.00)\end{array}$ & $\begin{array}{c}6.69 \\
(0.14)\end{array}$ & $\begin{array}{c}4.96 \\
(0.07)\end{array}$ & $\begin{array}{c}0.17 \\
(0.02)\end{array}$ & $\begin{array}{c}0.29 \\
(0.07)\end{array}$ & $\begin{array}{c}0.02 \\
(0.00)\end{array}$ & $\begin{array}{c}0.04 \\
(0.00)\end{array}$ \\
\hline & CDR22 & $\begin{array}{c}0.11 \\
(0.01) \\
\end{array}$ & $\begin{array}{c}0.09 \\
(0.02) \\
\end{array}$ & $\begin{array}{c}2.71 \\
(0.20) \\
\end{array}$ & $\begin{array}{c}4.31 \\
(0.36) \\
\end{array}$ & $\begin{array}{c}0.13 \\
(0.01) \\
\end{array}$ & $\begin{array}{c}0.39 \\
(0.03) \\
\end{array}$ & $\begin{array}{c}0.01 \\
(0.00) \\
\end{array}$ & $\begin{array}{r}0.02 \\
(0.00) \\
\end{array}$ \\
\hline \multicolumn{10}{|c|}{ Analysis of variance } \\
\hline \multicolumn{2}{|c|}{ As } & \multicolumn{2}{|l|}{$P<0.001$} & \multicolumn{2}{|c|}{$P<0.05$} & \multicolumn{2}{|c|}{$P=0.001$} & \multicolumn{2}{|c|}{$P<0.001$} \\
\hline \multicolumn{2}{|c|}{ Genotypes (G) } & \multicolumn{2}{|l|}{$P<0.001$} & \multicolumn{2}{|c|}{$P<0.001$} & \multicolumn{2}{|c|}{ NS } & \multicolumn{2}{|c|}{$P<0.001$} \\
\hline \multicolumn{2}{|c|}{$\mathrm{P}$} & \multicolumn{2}{|l|}{$P<0.001$} & \multicolumn{2}{|c|}{ NS } & \multicolumn{2}{|c|}{$P=0.001$} & \multicolumn{2}{|c|}{$P<0.001$} \\
\hline \multicolumn{2}{|c|}{ As $\times \mathrm{G}$} & \multicolumn{2}{|l|}{ NS } & \multicolumn{2}{|c|}{$P<0.01$} & \multicolumn{2}{|c|}{ NS } & \multicolumn{2}{|c|}{$P<0.05$} \\
\hline \multicolumn{2}{|c|}{ As $\times \mathrm{P}$} & \multicolumn{2}{|l|}{$P<0.05$} & \multicolumn{2}{|c|}{ NS } & \multicolumn{2}{|c|}{$P<0.05$} & \multicolumn{2}{|c|}{ NS } \\
\hline \multicolumn{2}{|c|}{$\mathrm{G} \times \mathrm{P}$} & $P<0.001$ & & $P<0$ & & & & & \\
\hline As $\times C$ & & NS & & $P<0$. & & & & & \\
\hline
\end{tabular}

a) Data in brackets represent the standard error.

Table 5 Iron plaques-to-root transference factors $\left(\mathrm{TF}_{\text {root }}\right)$ for $\mathrm{Fe}, \mathrm{P}$, As and $\mathrm{Cr}$ in two rice genotypes grown in solutions with $\mathrm{Cr}\left(1.0 \mathrm{mg} \mathrm{L}^{-1}\right)$ and different concentrations of As ${ }^{\text {a) }}$

\begin{tabular}{|c|c|c|c|c|c|c|c|c|c|}
\hline \multirow{2}{*}{ As $\left(\mathrm{mg} \mathrm{L}^{-1}\right)$} & \multirow{2}{*}{ Genotypes } & \multicolumn{2}{|c|}{$\mathrm{Fe}$} & \multicolumn{2}{|c|}{$\mathrm{P}$} & \multicolumn{2}{|c|}{ As } & \multicolumn{2}{|c|}{$\mathrm{Cr}$} \\
\hline & & $-\mathrm{P}$ & $+\mathrm{P}$ & $-\mathrm{P}$ & $+\mathrm{P}$ & $-\mathrm{P}$ & $+\mathrm{P}$ & $-\mathrm{P}$ & $+\mathrm{P}$ \\
\hline \multirow[t]{2}{*}{0} & $\operatorname{Jin} 23 \mathrm{~A}$ & $\begin{array}{c}0.46 \\
(0.07)\end{array}$ & $\begin{array}{c}0.20 \\
(0.07)\end{array}$ & $\begin{array}{c}2.09 \\
(0.11)\end{array}$ & $\begin{array}{c}1.82 \\
(0.15)\end{array}$ & - & - & $\begin{array}{c}0.46 \\
(0.06)\end{array}$ & $\begin{array}{c}0.78 \\
(0.20)\end{array}$ \\
\hline & CDR22 & $\begin{array}{c}0.23 \\
(0.03)\end{array}$ & $\begin{array}{c}0.09 \\
(0.01)\end{array}$ & $\begin{array}{c}1.54 \\
(0.18)\end{array}$ & $\begin{array}{c}1.55 \\
(0.28)\end{array}$ & - & - & $\begin{array}{c}0.26 \\
(0.02)\end{array}$ & $\begin{array}{c}0.32 \\
(0.04)\end{array}$ \\
\hline \multirow[t]{2}{*}{0.5} & Jin23A & $\begin{array}{c}0.29 \\
(0.02)\end{array}$ & $\begin{array}{c}0.13 \\
(0.02)\end{array}$ & $\begin{array}{c}2.81 \\
(0.08)\end{array}$ & $\begin{array}{c}1.90 \\
(0.11)\end{array}$ & $\begin{array}{c}6.57 \\
(0.36)\end{array}$ & $\begin{array}{l}10.80 \\
(0.63)\end{array}$ & $\begin{array}{c}0.42 \\
(0.02)\end{array}$ & $\begin{array}{c}0.55 \\
(0.05)\end{array}$ \\
\hline & CDR22 & $\begin{array}{c}0.13 \\
(0.02)\end{array}$ & $\begin{array}{c}0.09 \\
(0.01)\end{array}$ & $\begin{array}{c}1.29 \\
(0.14)\end{array}$ & $\begin{array}{c}1.41 \\
(0.14)\end{array}$ & $\begin{array}{c}3.11 \\
(0.74)\end{array}$ & $\begin{array}{l}12.38 \\
(2.19)\end{array}$ & $\begin{array}{c}0.22 \\
(0.05)\end{array}$ & $\begin{array}{c}0.29 \\
(0.03)\end{array}$ \\
\hline \multirow[t]{2}{*}{1.0} & $\operatorname{Jin} 23 \mathrm{~A}$ & $\begin{array}{c}0.20 \\
(0.03)\end{array}$ & $\begin{array}{c}0.07 \\
(0.00)\end{array}$ & $\begin{array}{c}3.17 \\
(0.12)\end{array}$ & $\begin{array}{c}1.36 \\
(0.07)\end{array}$ & $\begin{array}{c}6.10 \\
(0.42)\end{array}$ & $\begin{array}{c}9.19 \\
(1.05)\end{array}$ & $\begin{array}{c}0.35 \\
(0.02)\end{array}$ & $\begin{array}{c}0.36 \\
(0.02)\end{array}$ \\
\hline & CDR22 & $\begin{array}{c}0.09 \\
(0.01) \\
\end{array}$ & $\begin{array}{c}0.08 \\
(0.01) \\
\end{array}$ & $\begin{array}{c}1.38 \\
(0.13) \\
\end{array}$ & $\begin{array}{c}1.42 \\
(0.27) \\
\end{array}$ & $\begin{array}{c}1.73 \\
(0.28) \\
\end{array}$ & $\begin{array}{c}8.62 \\
(0.87) \\
\end{array}$ & $\begin{array}{c}0.28 \\
(0.01) \\
\end{array}$ & $\begin{array}{c}0.50 \\
(0.03) \\
\end{array}$ \\
\hline \multicolumn{10}{|c|}{ Analysis of variance } \\
\hline \multicolumn{2}{|c|}{ As } & \multicolumn{2}{|c|}{$P<0.001$} & \multicolumn{2}{|c|}{ NS } & \multicolumn{2}{|c|}{$P<0.05$} & \multicolumn{2}{|c|}{ NS } \\
\hline \multicolumn{2}{|c|}{ Genotypes (G) } & \multicolumn{2}{|c|}{$P<0.001$} & \multicolumn{2}{|c|}{$P<0.001$} & \multicolumn{2}{|c|}{$P<0.05$} & \multicolumn{2}{|c|}{$P<0.001$} \\
\hline \multicolumn{2}{|c|}{$\mathrm{P}$} & \multicolumn{2}{|c|}{$P<0.001$} & \multicolumn{2}{|c|}{$P<0.001$} & \multicolumn{2}{|c|}{$P<0.001$} & \multicolumn{2}{|c|}{$P=0.001$} \\
\hline \multicolumn{2}{|c|}{ As $\times \mathrm{G}$} & \multicolumn{2}{|c|}{$P<0.05$} & \multicolumn{2}{|c|}{$P<0.05$} & \multicolumn{2}{|c|}{ NS } & \multicolumn{2}{|c|}{$P=0.001$} \\
\hline \multicolumn{2}{|c|}{ As $\times \mathrm{P}$} & \multicolumn{2}{|c|}{$P<0.05$} & \multicolumn{2}{|c|}{$P<0.01$} & \multicolumn{2}{|c|}{ NS } & \multicolumn{2}{|c|}{ NS } \\
\hline \multicolumn{2}{|c|}{$\mathrm{G} \times \mathrm{P}$} & $P<$ & & $P<$ & & & & & \\
\hline As $x$ & & & & & & & & & \\
\hline
\end{tabular}

a) Data in brackets represent the standard error. 
Table 6 Distribution coefficients (DCs) of $\mathrm{Fe}, \mathrm{P}$, As and $\mathrm{Cr}$ between shoots and roots of two rice genotypes grown in solutions with $\mathrm{Cr}\left(1.0 \mathrm{mg} \mathrm{L}^{-1}\right.$ ) and different concentrations of As ${ }^{\text {a) }}$

\begin{tabular}{|c|c|c|c|c|c|c|c|c|c|}
\hline \multirow{2}{*}{ As $\left(\mathrm{mg} \mathrm{L}^{-1}\right)$} & \multirow{2}{*}{ Genotypes } & \multicolumn{2}{|c|}{$\mathrm{Fe}$} & \multicolumn{2}{|c|}{$\mathrm{P}$} & \multicolumn{2}{|c|}{ As } & \multicolumn{2}{|c|}{$\mathrm{Cr}$} \\
\hline & & $-\mathrm{P}$ & $+\mathrm{P}$ & $-\mathrm{P}$ & $+\mathrm{P}$ & $-\mathrm{P}$ & $+\mathrm{P}$ & $-\mathrm{P}$ & $+\mathrm{P}$ \\
\hline \multirow[t]{2}{*}{0} & Jin $23 \mathrm{~A}$ & $\begin{array}{c}0.94 \\
(0.03)\end{array}$ & $\begin{array}{c}0.84 \\
(0.23)\end{array}$ & $\begin{array}{c}2.56 \\
(0.06)\end{array}$ & $\begin{array}{c}3.34 \\
(0.09)\end{array}$ & - & - & $\begin{array}{c}0.12 \\
(0.01)\end{array}$ & $\begin{array}{c}0.10 \\
(0.01)\end{array}$ \\
\hline & CDR22 & $\begin{array}{c}0.88 \\
(0.05)\end{array}$ & $\begin{array}{c}1.01 \\
(0.04)\end{array}$ & $\begin{array}{c}2.54 \\
(0.08)\end{array}$ & $\begin{array}{c}2.95 \\
(0.38)\end{array}$ & - & - & $\begin{array}{c}0.13 \\
(0.01)\end{array}$ & $\begin{array}{r}0.11 \\
(0.02)\end{array}$ \\
\hline \multirow[t]{2}{*}{0.5} & Jin23A & $\begin{array}{c}1.23 \\
(0.06)\end{array}$ & $\begin{array}{c}0.84 \\
(0.04)\end{array}$ & $\begin{array}{c}2.51 \\
(0.11)\end{array}$ & $\begin{array}{c}3.42 \\
(0.07)\end{array}$ & $\begin{array}{c}0.05 \\
(0.01)\end{array}$ & $\begin{array}{c}0.07 \\
(0.01)\end{array}$ & $\begin{array}{c}0.09 \\
(0.00)\end{array}$ & $\begin{array}{c}0.08 \\
(0.01)\end{array}$ \\
\hline & CDR22 & $\begin{array}{c}0.89 \\
(0.08)\end{array}$ & $\begin{array}{c}0.89 \\
(0.04)\end{array}$ & $\begin{array}{c}2.38 \\
(0.14)\end{array}$ & $\begin{array}{c}3.00 \\
(0.09)\end{array}$ & $\begin{array}{c}0.11 \\
(0.01)\end{array}$ & $\begin{array}{c}0.11 \\
(0.02)\end{array}$ & $\begin{array}{c}0.10 \\
(0.01)\end{array}$ & $\begin{array}{c}0.09 \\
(0.00)\end{array}$ \\
\hline \multirow[t]{2}{*}{1.0} & Jin $23 \mathrm{~A}$ & $\begin{array}{c}1.18 \\
(0.10)\end{array}$ & $\begin{array}{c}0.98 \\
(0.01)\end{array}$ & $\begin{array}{c}2.12 \\
(0.08)\end{array}$ & $\begin{array}{c}3.66 \\
(0.20)\end{array}$ & $\begin{array}{c}0.03 \\
(0.00)\end{array}$ & $\begin{array}{c}0.03 \\
(0.01)\end{array}$ & $\begin{array}{c}0.06 \\
(0.01)\end{array}$ & $\begin{array}{c}0.05 \\
(0.01)\end{array}$ \\
\hline & CDR22 & $\begin{array}{c}0.94 \\
(0.03) \\
\end{array}$ & $\begin{array}{c}1.02 \\
(0.10) \\
\end{array}$ & $\begin{array}{c}1.99 \\
(0.10) \\
\end{array}$ & $\begin{array}{c}3.24 \\
(0.36) \\
\end{array}$ & $\begin{array}{c}0.08 \\
(0.01) \\
\end{array}$ & $\begin{array}{c}0.05 \\
(0.01) \\
\end{array}$ & $\begin{array}{c}0.04 \\
(0.00) \\
\end{array}$ & $\begin{array}{c}0.05 \\
(0.01)\end{array}$ \\
\hline \multicolumn{10}{|c|}{ Analysis of variance } \\
\hline \multicolumn{2}{|c|}{ As } & \multicolumn{2}{|c|}{$P<0.05$} & \multicolumn{2}{|c|}{ NS } & \multicolumn{2}{|c|}{$P<0.001$} & \multicolumn{2}{|c|}{$P<0.001$} \\
\hline \multicolumn{2}{|c|}{ Genotypes (G) } & \multicolumn{2}{|c|}{ NS } & \multicolumn{2}{|c|}{$P<0.05$} & \multicolumn{2}{|c|}{$P<0.001$} & \multicolumn{2}{|c|}{ NS } \\
\hline \multicolumn{2}{|c|}{$\mathrm{P}$} & \multicolumn{2}{|c|}{$P<0.05$} & \multicolumn{2}{|c|}{$P<0.001$} & \multicolumn{2}{|c|}{ NS } & \multicolumn{2}{|c|}{ NS } \\
\hline \multicolumn{2}{|c|}{ As $\times \mathrm{G}$} & \multicolumn{2}{|c|}{ NS } & \multicolumn{2}{|c|}{ NS } & \multicolumn{2}{|c|}{$P<0.001$} & \multicolumn{2}{|c|}{$P<0.001$} \\
\hline \multicolumn{2}{|c|}{ As $\times \mathrm{P}$} & \multicolumn{2}{|c|}{ NS } & \multicolumn{2}{|c|}{$P<0.01$} & \multicolumn{2}{|c|}{ NS } & \multicolumn{2}{|c|}{$P<0.01$} \\
\hline \multicolumn{2}{|c|}{$\mathrm{G} \times \mathrm{P}$} & & & & & & & & \\
\hline & & & & & & & & & \\
\hline
\end{tabular}

a) Data in brackets represent the standard error.

Both shoots and roots accumulated a large amount of $\mathrm{Fe}$, while P mainly accumulated in the shoots. Without the addition of $\mathrm{P}$, the distribution coefficients (DCs) of $\mathrm{P}$ in Jin23A and CDR22 were respectively 2.12-2.56 and 1.99-2.54, and with $\mathrm{P}$ addition, the DCs of $\mathrm{P}$ were respectively 3.34-3.66 and 2.95-3.24 (Table 6). The DC of Fe in shoots and roots was significantly affected by the addition of As and $\mathrm{P}$ to the solution $(P<0.05)$, but the DC of $\mathrm{P}$ suffered little impact.

Arsenic mainly accumulated in rice roots. The DC of As was $0.03-0.07$ for Jin23A and 0.05-0.11 for CDR22 under different As concentrations in the solution (Table 6). The DC of As in shoots and roots of both rice genotypes significantly decreased with the increase of As in the nutrient solution $(P<0.001)$, while $\mathrm{P}$ did not influence the DC of As. Similarly as with As, $\mathrm{Cr}$ also primarily accumulated in rice roots. The $\mathrm{DC}$ of $\mathrm{Cr}$ was $0.05-0.12$ for Jin23A and 0.04-0.13 for CDR22 (Table 6). The DC of Cr in shoots and roots of both rice genotypes decreased with the increase of As concentration in nutrient solution $(P<0.001)$, but showed little response to $\mathrm{P}$.

\section{Discussion}

As and $\mathrm{Cr}$ are not necessary elements for plant growth, and excess exposure to them might poison plants. According to our experiments, the impact of complex contamination of As and $\mathrm{Cr}$ on plant height, root length and root biomass did not seem high, but shoot biomass vigorously responded (Table 1). The biomass of the plant parts under and above ground both significantly reduced due to As poisoning [17].
The rice biomass reduction caused by $\mathrm{Cr}$ poisoning was also reported by scientists [18]. However, some studies showed that the addition of a low concentration of As and Cr stimulated the growth of crops and thus increased crop yield $[19,20]$.

There is a complicated interaction between As and $\mathrm{P}$ in plants. As and $\mathrm{P}$ have a similar atomic structure. When As combines with 3-P-glyceraldehydes, ATP production is inhibited and hence the processes of phosphorylation and oxidative phosphorylation of cells are influenced. Some reports indicated that As poisoning may close the channel of plants for $\mathrm{P}$ uptake so that plant $\mathrm{P}$ uptake is inhibited $[21,22]$. However we found that As did not influence the concentration of $\mathrm{P}$ in rice roots and shoots in our experiments. The reason might lie in the more complicated mechanism of complex contamination than with a single contaminant. P might influence As uptake and accumulation in plants. According to Geng et al. [23], the application of enough $\mathrm{P}$ counteracted the poisoning effect of As and thus eliminated the symptoms of As poisoning. In our experiments, the plant height and dry weight of rice roots and shoots were significantly higher under the treatments with $\mathrm{P}$ addition than without $\mathrm{P}$, indicating that $\mathrm{P}$ relieves the poisoning effect of As and Cr. For treatment of $0.5 \mathrm{mg} \mathrm{L}^{-1}$ $\mathrm{As}^{3+}+1.0 \mathrm{mg} \mathrm{L}^{-1} \mathrm{Cr}^{3+}$ and $1.0 \mathrm{mg} \mathrm{L}^{-1} \mathrm{As}^{3+}+1.0 \mathrm{mg} \mathrm{L}^{-1} \mathrm{Cr}^{3+}$, the As concentrations in rice roots were $7.7 \%-35.5 \%$ and $11.2 \%-31.1 \%$ higher in the presence of $\mathrm{P}$ than without $\mathrm{P}$ addition. Similarly, Geng et al. found that As concentrations in the shoots and roots of the two rice genotypes 94D-54 and 94D-64 largely increased with the increase of $\mathrm{P}$ in the solution [23].

The mechanism of plant $\mathrm{Cr}$ uptake is more complicated, 
and other elements influence $\mathrm{Cr}$ uptake and accumulation. Plants uptake both $\mathrm{Cr}(\mathrm{III})$ and $\mathrm{Cr}$ (VI) [10,24], however the uptake of $\mathrm{Cr}(\mathrm{III})$ is by a passive process, while $\mathrm{Cr}(\mathrm{VI})$ uptake proceeds through a sulfate carrier [25]. In our experiments, the addition of $\mathrm{Cr}$ (III) in solution resulted in a high $\mathrm{Cr}$ uptake and accumulation in rice, and the shoot $\mathrm{Cr}$ concentrations under the cultures with $\mathrm{P}$ addition were lower than without $\mathrm{P}$. The application of As facilitates the uptake and accumulation of $\mathrm{Cr}$ in shoots and roots. Shewry and Peterson reported that plant $\mathrm{Cr}$ uptake is inhibited by hexavalent ions, such as $\mathrm{SO}_{4}{ }^{2-}$, but $\mathrm{Ca}^{2+}$ promotes plant $\mathrm{Cr}$ uptake [26]. Similarly, chromium contamination also influences the uptake of other elements. Mora et al. found that $\mathrm{Cr}(\mathrm{III})$ significantly reduced the $\mathrm{Fe}$ and $\mathrm{Cu}$ uptake and accumulation by tomatoes [27]. The effects of $\mathrm{Cr}(\mathrm{III})$ on the uptake of major elements $(\mathrm{P}, \mathrm{Ca}, \mathrm{K}$ and $\mathrm{Mg}$ ) and minor elements $(\mathrm{Fe}, \mathrm{Cu}$ and $\mathrm{Zn})$ in tumbleweed were reported by Gardea-Torrestdey et al. [12]. Similarly, the effects of $\mathrm{Cr}$ (III) on the uptake and accumulation of Fe, P, As and $\mathrm{Cr}$ in rice were investigated in this study, but the mechanism of As (III) and $\mathrm{Cr}$ (III) complex contamination might be more complicated than that of single $\mathrm{Cr}$ (III) contamination.

Phosphorous application in a cultural solution significantly increases the concentrations of $\mathrm{Fe}$ and $\mathrm{P}$ in the iron plaque, and reduce As and $\mathrm{Cr}$ concentrations. The concentrations of $\mathrm{As}$ and $\mathrm{Cr}$ in iron plaque of rice increased with the increase of As concentration in solution, but the concentrations of $\mathrm{Fe}$ and $\mathrm{P}$ in the iron plaque were not significantly influenced, indicating that the impact of the iron plaque on plant element uptake mechanism may be very complicated. Through X-ray fluorescence microscopy, Batty et al. found that the iron plaque mainly consists of Fe and Mn oxides and their hydroxides [28]. Iron plaque has a special electrochemical characteristic so that it's an amphoteric colloid. It changes the existing form of anions and cations of heavy metal around plant roots through actions of adsorption and desorption, oxidation and reduction, and organic or inorganic complexation, thus it influences the biological availability of the ions [29,30]. Rice iron plaque strongly induces the formation of arsenate, which forms a buffer zone in the root microenvironment to inhibit the accumulation of toxic chemicals in rice tissues [31]. Therefore, investigation of the uptake and accumulation of $\mathrm{As}$ and $\mathrm{Cr}$ by rice in the presence of a root surface iron plaque provides a scientific basis for phytoremediation by heavy metals.

\section{Conclusion}

This study indicated that the effect of the complex contamination of As and $\mathrm{Cr}$ on rice shoot dry weight is significant, although not so on plant height, root length and root dry weight. The concentration of $\mathrm{P}$ (or As) in rice shoots is significantly increased with P (or As) application. Application of $\mathrm{P}$ and $\mathrm{As}$ in a cultural solution significantly reduces the concentrations of $\mathrm{Fe}$ in the shoots and roots of the two rice genotypes. The root As concentration is significantly affected by the addition of $\mathrm{P}$ in the solution, while $\mathrm{P}$ concentrations in roots and shoots are not significantly influenced by As addition. Application of $\mathrm{P}$ in the solution results in a decrease of rice shoot $\mathrm{Cr}$ concentration, but the application of As leads to an increase of shoot $\mathrm{Cr}$ concentration.

Concentrations of $\mathrm{As}$ and $\mathrm{Cr}$ in the iron plaque of the two rice genotypes are significantly affected by the addition of As in the solution. Phosphorous addition in the solution largely increases the concentrations of $\mathrm{Fe}$ and $\mathrm{P}$ while significantly decreasing the concentrations of $\mathrm{As}$ and $\mathrm{Cr}$ in the iron plaque. Through the comparison of elemental transference factors (TFs), it is evident that phosphorous transfers from the iron plaque to rice roots and shoots, but the transferences of $\mathrm{Cr}$ and $\mathrm{Fe}$ are lower, and As is also lower. The transferences of $\mathrm{As}$ and $\mathrm{Cr}$ from the iron plaque to rice roots and shoots are influenced by $\mathrm{P}$ management. The influence of $\mathrm{P}$ addition on $\mathrm{As}$ and $\mathrm{Cr}$ in rice grains was not found in this study, because rice was harvested before experiencing an entire growing season. If $\mathrm{P}$ management reduces the accumulation of $\mathrm{As}$ and $\mathrm{Cr}$ in rice grains, it would provide a fundamental guiding role for As and $\mathrm{Cr}$ contamination prevention in rice fields.

This work was supported by the National Natural Science Foundation of China (Grant Nos. 30671204 and 40620120436), the Knowledge Innovation Project of the Chinese Academy of Sciences (Grant No. KSCX2$Y W-N-41-05)$, and the National Major Programs of Water Pollution Control (Grant No. 2008ZX07212-001-05).

1 Boyle R W, Jonasson I R. The geochemistry of As and its use as an indicator element in geochemical prospecting. $\mathrm{J}$ Geochem Explor, 1973, 2: 251-296

2 Ure A, Berrow M. The elemental constituents of soils. In: Bowen H J M. (Ed). Environmental Chemistry. London: Royal Society of Chemistry, 1982. 94-203

3 Mandal B K, Suzuki K T. Arsenic round the world: A review. Talanta, 2002, 58: 201-235

4 Song S Q, Liang L F, Zhou Y Z, et al. The situation and remedial measures of the cropland polluted by heavy metals from mining along the DiaoJiang River. Bull Mineral Petrol Geochem, 2003, 22: $152-155$

5 Liao X Y, Chen T B, Xiao X Y, et al. Spatial distributions of arsenic in contaminated paddy soils. Geography Res, 2003, 22: 635-643

6 Meharg A A, Rahman M. Arsenic contamination of Bangladesh paddy field soils: Implications for rice contribution to arsenic consumption. Environ Sci Technol, 2003, 37: 229-234

7 Duxbury J M, Mayer A B, Lauren J G, et al. Food-chain aspects of arsenic in Bangladesh: effects on quality and productivity of rice. Environ Sci Health, Part A, 2003, 38: 61-69

8 Patel K S, Shrivas K, Brandt R, et al. Arsenic contamination in water, soil, sediment \& rice of central India. Environ Geochem Health, 2005, 27: $131-145$

9 Abedin M J, Cresser M S, Meharg A A, et al. Arsenic accumulation and metabolism in rice (Oryza sativa L.). Environ Sci Technol, 2002, 36: 962-968

10 Zayed A, Lytle C M, Qian J H, et al. Chromium accumulation, translocation and chemical speciation in vegetable crops. Planta, 1998, 
206: 293-299

11 Wani P A, Khan Md S, Zaidi A. Chromium-reducing and plant growth-promoting Mesorhizobium improves chickpea growth in chromium-amended soil. Biotechnol Lett, 2008, 30: 159-163

12 Gardea-Torresdey J L, de la Rosa G, Peralta-Videa J R, et al. Differential uptake and transport of trivalent and hexavalent chromium by tumbleweed (Salsola kali). Arch Environ Contam Toxicol, 2005, 48: 225-232

13 Kim M J, Ahn K H, Jung Y, et al. Arsenic, cadmium, chromium, copper, lead, and zinc contamination in mine tailings and nearby streams of three abandoned mines from Korea. Bull Environ Contam Toxicol, 2003, 70: 942-947

14 Liu W J, Zhang X K, Yin J, et al. Effect of P stress on morphology of rice roots and uptake of $\mathrm{Fe}, \mathrm{Mn}, \mathrm{Cu}, \mathrm{Zn}$ by four rice genotypes. Ecol Environ, 2003, 12: 49-51

15 Meharg A A, Jardine L. Arsenite transport into paddy rice (Oryza sativa) roots. New Phytologist, 2003, 157: 39-44

16 Zhu Y G, Huang Y Z, Hu Y, et al. Iodine uptake by spinach (Spinacia oleracea L.) plants grown in solution culture: effects of iodine species and solution concentrations. Environ Internat, 2003, 29: 33-37

17 Abedin M J, Cotter-Howells J, Meharg A A. Arsenic uptake and accumulation in rice (Oryza sativa L.) irrigated with contaminated water. Plant Soil, 2002, 240: 311-319

18 Dong J, Wu F B, Huang R G, et al. A chromium-tolerant plant growing in Cr-contaminated land. Internat J Phytoremed, 2007, 9: 167-179

19 Bonet A, Poschenrieder C, Barcelo J. Chromium III-iron interaction in Fe-deficient and Fe-sufficient bean plants. I. Growth and nutrient content. J Plant Nutr, 1991, 14: 403-414

20 Onken B M, Hossner L R J. Plant uptake and determination of arsenic species in soil solution under flooded conditions. J Environ Qual, 1995, 24: 373-381
21 Cox M S, Kovar J L. Soil arsenic effects on Canola seedling growth and ion uptake. Commun Soil Sci Plant, 2001, 32: 107-117

22 Meharg A A, Macnair M R. Suppress of the high affinity phosphate uptake system: a mechanism of arsenate tolerance in Horus lanatus $\mathrm{L}$. J Exp Bot, 1992, 43: 519-524

23 Geng C N, Zhu Y G, Liu W J, et al. Arsenate uptake and translocation in seedlings of two genotypes of rice is affected by external phosphate concentrations. Aquatic Botany, 2005, 83: 321-331

24 McGrath S P. The uptake and translocation of tri- and hexavalent $\mathrm{Cr}$ and effects on the growth of oat in flowing nutrient solution and in soil. New Phytol, 1982, 92: 381-390

25 Skeffington R A, Shewry P R, Peterson P J. Chromium uptake and transport in barley seedlings (Hordeum vulgare L.). Planta, 1976, 132: 209-214

26 Shewry P R, Peterson P J. The uptake and transport of chromium by barley seedlings (Hordeum vulgare L.). J Exp Bot, 1974, 25: 785-797

27 Mora R, Gomez I, Navarro P, et al. Absorption of $\mathrm{Cr}$ and effects on micronutrient content in tomato plant (Lycopersicum esculentum). Agrochimica, 1996, 40: 132-138

28 Batty L C, Baker A J M, Wheeler B D, et al. The effect of pH and plaque on the uptake of $\mathrm{Cu}$ and $\mathrm{Mn}$ in Phragmites australis (Cav) Trin Ex Steudel. Ann Bot, 2000, 86: 647-653

29 Otte M L, Rozema J, Koster L, et al. Iron plaque on roots of Aster tripolium L.: interaction with zinc uptake. New Phytol, 1989, 111: 309-317

30 St-Cyr L, Crowder A A. Manganese and copper in the root plaque of Phragmites australis (Cav) Trin.ex Steudel. Soil Sci, 1990, 149: 191-198

31 Liu W J, Zhu Y G, Smith F A, et al. Do phosphorus nutrition and iron plaque alter arsenate (As) uptake by rice seedlings in hydroponic culture? New Phytologist, 2004, 162: 481-488 